\title{
Amphibole compositions as indicators of deep crustal and mantle processes in subduction zones: case study - Tso Morari metamafics, Ladakh, Himalaya
}

\author{
Preeti Singh ${ }^{1 *}$, NC Pant ${ }^{2}$, A Kundu ${ }^{2}$, T Ahmad $^{1}$ and PK Verma ${ }^{1}$ \\ 1 Department of Geology, University of Delhi, Delhi-110007, INDIA \\ 2 EPMA Laboratory, Geological Survey of India, NH-5, Faridabad N.I.T.- 110005, INDIA \\ * For correspondence, email: preetisingh64@yahoo.co.in
}

Amphiboles have large number of cationic sites where substitution by various elements is a rule in response to changes in environmental conditions (Veblen 1985). The environmental conditions include hydrostatic pressure, temperature, $\mu_{\mathrm{H} 2 \mathrm{O}}, \mathrm{f}_{\mathrm{O} 2}$ etc. Experimental and empirical data are available to correlate these factors with mineral compositions for many amphibole species. These criteria have been utilized to study a natural example of ultra-high pressure metamorphism from the Himalaya.

A small area in SE Ladakh, just south of the Indus Suture Zone has been a subject of intense study recently (de Sigyore et al. 2000, 2004, Guillot et al. 2000, 2008, Jain et al. 2003) because of the implications of geologic and geochronologic studies on the tectonic nature of Plate Subduction mechanism. Singh and Verma (2006) have shown for this area how compositions of phengite and biotite of metamafics (forming boudins in the host feldspar gneisses) and the host rocks respond to various stages of subduction and exhumation of plates.

Amphiboles are also important constituents of the metamafic boudins present in the Tso Morari region. from the point of view of phase relationships Verma et al. (2008) have shown that the metamafics are characterized by five assemblages. Two of these five assemblages are UHPM indicators while one belongs to HPM.

In the present study, a large dataset of chemical composition data through EPMA on relevant phases including amphiboles has been utilized to fine-tune the P-T- $\mu_{\mathrm{H} 2 \mathrm{O}}-\mathrm{f}_{\mathrm{O} 2}$ values of the P$\mathrm{T}-\mathrm{t}$ path (subduction as well as exhumation components). Naamphibole including glaucophane (Amphibole nomenclature after Leake et al. 1997) is present in cores of the zoned garnets in assemblage i) where it coexists with epidote and paragonite (HPM assemblage). Assemblage ii) is UHPM assemblage without any amphibole. $\mathrm{Na}-\mathrm{Ca}$ ampbhiloes, taramite and magnesiokataphorite form assemblage iii), where these occur with garnet and phengite (UHPM assemblages). These amphiboles also occur as inclusions in some garnet grains. A continuous progressive reaction has even generated barroisite and rare winchite compositions in amphiboles that form part of this assemblage in the matrix. Caamphiboles occur as part of assemblages iv), and v) which contain albite, chlorite and biotite with another continuous reaction sequence in amphiboles, chlorites and biotite. These assemblages are correlated with different stages of subduction and exhumation on the basis of textures as well as thermobarometry.

\section{References}

de Sigoyer J, V Chavagnac, JB Toft, IM Villa, B Luais, S Guillot, M Cosca and G Mascle. 2000. Dating the Indian continental subduction and collisional thickening on the NW Himalayas-Multichronology of the Tso Morari eclogites. Geology 28: 487-490

de Sigoyer J, S Guillot and P Dick. 2004. Exhumation of the UltrahighPressure Tso Morari unit in eastern Ladakh (NW Himalayas): A case study. Tectonics 23: 1-18

Guillot S, KHHattoriand J de Sigoyer. 2000. Mantle wedge serpentinization and exhumation of eclogites: Insights from Eastern Ladakh, NW Himalayas. Geology 28: 199-202

Guillot S, G Maheo, J de Sigoyer, KH Hattori and A Pecher. 2008. Tethyan and Indian subduction viewed from the Himalayan high to ultrahigh pressure metamorphism. Tectonophysics 451: 225-241

Jain AK, S Singh, RM Manickavasagam, M Joshi and PK Verma. 2003. HIMPROBE Programme: Integrated studies on geology, petrology, geochronology, and geophysics of the Trans Himalaya and Karakoram. Memoir Geological Society of India No 53: 1-56

Leake BE, AR Woolley, CES Arps, WD Birch, MC Gilbert, JD Grice, FC Hawthorne, A Kato, HJ Kisch, VG Krivovichev, K Linthout, J Laird and J Mandarino. 1997. Nomenclature of amphiboles. Report of the subcommittee on amphiboles of the International Mineralogical Association: Commission on new mineral names. Mineralogical Magzine 61: 295-321

Singh P and Verma PK. 2006. Petrogenetic Significance of Phengite and Biotite from the Ladakh UHP Terrain, Northwest Himalayas. Indian Journal of Geochemistry 2(1): 25-48

Veblen DR. 1985. Amphiboles and other hydrous pyriboles-mineralogy. Reviews in Mineralogy, Mineralogical Society of America 9A, 372 pp

Verma P, AB Thompson, P Singh, N Pant, A Kundu, T Ahmad, S Sengupta, A Saikia, S Deol. 2008. New insights on the mechanism of exhumation of deep crustal rocks in the light of new petrologic data on eclogites and coesite locations in the Lake Morari region, NW Himalayas. (Under Review) 